\author{
JURNAL Midwifery Update (MU) \\ http://jurnalmu.poltekkes-mataram.ac.id/index.php/jurnalmu \\ e-ISSN:2684-8511 (Online)
}

\title{
PENDIDIKAN DAN PENGETAHUAN DALAM PEMANFAATAN PELAYANAN KONTRASEPSI PADA PASANGAN USIA SUBUR DI PUSKESMAS KARANG INTAN 2 KABUPATEN BANJAR
}

\author{
Rita Kirana ${ }^{1}$ dan Wardah Tilah Yuliani ${ }^{2}$ \\ ${ }^{1}$ Jurusan Kebidanan Poltekkes Kemenkes Banjarmasin \\ ${ }^{2}$ AKBID Banua Bina Husada Banjarbaru
}

\begin{abstract}
Abstrak
Pemberian pelayanan alat kontrasepsi adalah upaya yang dilakukan untuk meningkatkan kualitas keluarga. Selama kurun waktu dua dasawarsa, pelayanan kontrasepsi dalam pembangunan KB di Indonesia telah memperoleh hasil yang cukup menggembirakan. Pada SDKI tahun 2003 ada sebesar 57,4\% wanita menikah yang memakai alat kontrasepsi. SDKI 2007 didapatkan data sebesar 61,4\% wanita menikah yang memakai alat kontrasepsi SDKI 2008. Tujuan penelitian ini adalah untuk mengetahui pendidikan dan pengetahuan dengan pemanfaatan pelayanan kontrasepsi pada pasangan usia subur di Puskesmas Karang Intan 2 Kabupaten Banjar. Metode penelitian kuantitatif dengan pendekatan cross sectional study yang dimaksudkan untuk mengetahui dinamika hubungan antara variabel independen dengan variabel dependen. Hasil yang diperoleh pada penelitian ini tidak ada hubungan antara pendidikan dengan pemanfaatan pelayanan alat kontrasepsi $\mathrm{KB}(\mathrm{p}=0,209)$ dan terdapat hubungan antara pengetahuan dengan pemanfaatan pelayanan alat kontrasepsi KB pada PUS $(\mathrm{p}=0,016)$. Disarankan bagi petugas kesehatan memberikan informasi tentang pemanfaatan pelayanan alat kontrasepsi $\mathrm{KB}$ pada pasangan usia subur untuk meningkatkan pengetahuan tentang penggunaan alat kontrasepsi.
\end{abstract}

Kata kunci : Pengetahuan ; Pelayanan Kontrasepsi ; PUS

\begin{abstract}
The provision of contraceptive services is an effort made to improve the quality of the family. Over the past two decades, contraceptive services in the development of family planning in Indonesia have received quite encouraging results. In the 2003 IDHS, 57.4\% of married women were using contraception. The 2007 IDHS data showed $61.4 \%$ of married women who used the 2008 IDHS contraception The purpose of this study was to determine the factors associated with the use of contraceptive services in infertile couples in Karang Intan 2 Health Center, Banjar District. Quantitative research methods with a cross sectional study approach that is intended to education and knowledge the dynamics of the relationship between independent variables with the dependent variable. There was no relationship between education and the use of family planning contraception services at PUS $2019(\mathrm{p}=0.209)$ and there is a relationship between knowledge and the use of family planning contraception services at PUS $(p=0.016)$. It is recommended for health workers to provide information about the use of contraceptive services in fertile age couples to increase knowledge about the use of contraceptives.
\end{abstract}

Keywords: Knowledge ; Contraceptive Services ; PUS

\section{Pendahuluan}

Pemberian pelayanan alat kontrasepsi adalah upaya yang dilakukan untuk meningkatkan kualitas keluarga. Selama kurun waktu dua dasawarsa, pelayanan kontrasepsi dalam pembangunan KB di Indonesia telah memperoleh hasil yang cukup menggembirakan. Walaupun pada satu dasawarsa terakhir seakan-akan program KB terdengar lemah kegiatannya, namun ternyata dari data SDKI 2007 program KB ada 
keberhasilannya. Yakni ditandai dengan semakin meningkatnya prevalensi wanita usia subur yang menggunakan metode kontrasepsi. Pada SDKI tahun 2003 ada sebesar 57,4\% wanita menikah yang memakai alat kontrasepsi. Sedangkan pada SDKI 2007 didapatkan data sebesar $61,4 \%$ wanita menikah yang memakai alat kontrasepsi SDKI $2008 .^{2}$

Program keluarga berencana ada di Republik Indonesia bertujuan untuk membangun manusia Indonesia sebagai objek dan subjek pembangunan melalui peningkatan kesejahteraan ibu, anak, dan keluarga. Selain itu program KB juga digunakan untuk menurunkan angka kelahiran bayi dengan memakai cara yaitu menggunakan salah satu dari jenis kontrasepsi secara sukarela yang didasari oleh adanya keinginan dan tanggung jawab bagi para peserta program KB dan seluruh lapisan masyarakat. Upaya - upaya tersebut adalah sebagai salah satu dari sekian banyak langkah nyata dalam rangka untuk menurunkan angka kelahiran bayi sekaligus pembentukan keluarga sejahtera merupakan cerminan dari program KB. ${ }^{2}$

Di wilayah Provinsi Kalimantan selatan, persentase tertinggi metode kontrasepsi yang di pakai peserta KB aktif adalah metode kontrasepsi suntik (47,39\%), kemudian metode kontrasepsi PIL (22,90\%), metode kontrasepsi Kondom (13,45\%,) dan metode kontrasepsi lain-lainnya (0,56\%). Sedangkan pada persentase penggunaan kontrasepsi bagi peserta program KB baru yang terbanyak metode kontrasepsi suntikan (44,61\%), metode kontrasepsi Pil (24,78\%), metode kontrasepsi Kondom (16,85\%), metode kontrasepsi Implant (8,84\%), metode kontrasepsi IUD (3,21\%), metode kontrasepsi MOW 1,04\%), metode kontrasepsi MOP $(0,25 \%)$ dan metode kontrasepsi lainnya $(0,28 \%))^{5}$

Pada wilayah kerja Puskesmas Karang Intan 2 yang berada di Kabuten Banjar, memiliki cakupan peserta kontrasepsi yang mengalami trend peningkatan dari tahunke tahunnya. Pada tahun 2015 sebesar 1507 akseptor (25,8\%) pada tahun 2016 sebesar 3011 akseptor (51,5\%) pada tahun 2017 sebesar 3332 akseptor $(56,9 \%) .{ }^{10}$

Penelitian yang di lakukan Rifai (2013), menyampaikan bahwa ada hubungan antara pengetahuan dan pendidikan dengan penggunaan alat kontrasepsi pada pasangan usia subur $(\mathrm{p}=0,000)$. Ada hubungan antara ketersedian alat kontrasepsi dengan penggunaaan alat kontrasepsi pada pasangan usia subur $(\mathrm{p}=0,000)$ dan tidak ada hubungan antara jumlah anak dengan penggunaaan alat kontrasepsi pada pasangan usia subur di Wilayah Kerja Puskesmas Buhu Kabupaten Gorontalo ( $p=0,222 \leq$ nilai $\alpha=0,05$ ).

\section{Metode}

Metode penelitian yang digunakan adalah penelitian kuantitatif dengan pendekatan cross sectional study yang dimaksudkan untuk mengetahui dinamika hubungan antara variabel independen dengan variabel dependen, berlokasi di Puskesmas Karang Intan 2 Kecamatan Karang Intan Kabupaten Banjar. Populasi dalam penelitian ini adalah semua pasangan usia subur yang berada di wilayah Puskesmas Karang Intan 2 Kabupaten Banjar selama tahun 2018 yang berjumlah 3.697 orang. Sampel adalah bagian dari populasi yang akan di teliti sampel dalam penelitian ini adalah pasangan usia subur (PUS) di Puskesmas Karang Intan 2 sejumlah 100 orang PUS dengan teknik pengambilan Accidental Sampling. 


\section{Hasil dan Pembahasan}

\section{Pendidikan}

Tabel 1. Distribusi Frekuensi Berdasarkan Pendidikan Di Puskesmas Karang Intan 2 Tahun 2019

\begin{tabular}{|c|c|c|c|}
\hline No & Pendidikan & Frekuensi & Persentase (\%) \\
\hline 1 & Rendah & 13 & 13,0 \\
\hline 2 & Tinggi & 87 & 87,0 \\
\hline & Jumlah & 100 & 100,0 \\
\hline
\end{tabular}

Berdasarkan Tabel 4.4 menunjukkan bahwa PUS yang berpendidikan rendah di wilayah kerja Puskesmas Karang Intan 2 adalah sebanyak 13 orang (13,0\%) dan PUS yang berpendidikan tinggi di wilayah kerja Puskesmas Karang Intan 2 adalah sebanyak 87 orang $(87,0 \%)$

Notoatmodjo (2012) mengemukakan bahwa pendidikan itu sendiri amat di perlukan seseorang agar lebih tanggap terhadap pemilihan alat kontrasepsi yang cocok dan aman. Sehingga dalam penggunaannya akan lebih teratur dan sesuai dengan aturan penggunaannya. Tingkat pendidikan turut menentukan rendah tidaknya seseorang menyerap dan memadai pengetahuan, demikian halnya dengan ketidakteraturan dalam penggunaan alat kontrasepsi suntik. ${ }^{6}$

Pada penelitian ini menunjukan bahwa masih ada PUS yang memiliki pendidikan rendah menggunakan kontrasepsi. Penelitian ini menunjukan bahwa kebanyakannya PUS yang memanfaatkan pelayanan kontrasepsi yang memilik pendidikan tinggi. Hal ini sejalan dengan penelitian Grestasari yang menyatakan tidak ada hubungan antara tingkat pendidikan dengan pemilihan jenis kontrasepsi. ${ }^{6}$ Adyani juga menyatakan hal yang sama bahwa faktor tingkat pendidikan tidak memiliki hubungan yang signifikan dengan pemilihan jenis kontrasepsi pada akseptor wanita usia 20-39 tahun. ${ }^{1}$

Menurut Mantra (2012), tingkat pendidikan merupakan faktor non demografi yang dapat mempengaruhi tingkat fertilitas. Namun, tingkat pendidikan bukan merupakan variabel yang secara langsung dapat mempengaruhi fertilitas. Tingkat pendidikan merupakan salah satu faktor non demografi yang berkaitan dengan pengetahuan PUS tentang manfaat dari penggunaan alat kontrasepsi dan pengendalian kelahiran, sehingga dapat menekan tingkat fertilitas dan meningkatkan kualitas penduduk. Dari hasil uji hipotesis menunjukkan bahwa wanita PUS yang memiliki jumlah anak yang dilahirkan lebih banyak adalah wanita PUS yang menggunakan alat kontrasepsi jangka pendek (Non MKJP) dan sebagian besar wanita PUS tersebut memiliki tingkat pendidikan yang rendah. ${ }^{9}$

\section{Pengetahuan}

Tabel 4.5. Distribusi Frekuensi Berdasarkan Pengetahuan Di Puskesmas Karang Intan 2 Tahun 2019

\begin{tabular}{|c|c|c|c|}
\hline No & Pengetahuan & Frekuensi & Persentase (\%) \\
\hline 1 & Kurang & 36 & 36,0 \\
\hline 2 & Cukup & 64 & 64,0 \\
\hline & Jumlah & 100 & 100,0 \\
\hline
\end{tabular}


Berdasarkan Tabel 4.5 menunjukkan bahwa PUS yang berpengetahuan kurang di wilayah kerja Puskesmas Karang Intan 2 sebanyak 36 orang (36,0\%) dan PUS yang berpengetahuan cukup di wilayah kerja Puskesmas Karang Intan 2 sebanyak 64orang $(64,0 \%)$

Pengetahuan merupakan hasil dari seseorang yang tahu dan akan terjadi setelah orang tersebut melakukan penginderaan terhadap suatu objek tetentu. Pengindraan terjadi melalui pancaindra manusia yakni melalui indra penglihatan, penciuman, pendengaran perasa, dan peraba. Pengetahuan atau kognitif merupakan domain yang sangat penting dalam membentuk tindakan seseorang. Pengetahuan yang baik atau dapat menunjang tindakan seseorang dalam menggunakan suatu layanan kesehatan dan patut terhadap aturan penggunaannya. ${ }^{6}$ Hal ini sesuai dengan teori Mubarok (2007) yang menyatakan salah satu faktor yang mempengaruhi pengetahuan adalah tingkat pendidikan. Makin tinggi pendidikan seseorang semakin mudah pula mereka menerima informasi, dan pada akhirnya makin banyak pula pengetahuan yang dimilikinya. Sebaliknya jika tingkat pendidikannya rendah, akan menghambat perkembangan sikap seseorang terhadap penerimaan, informasi dan nilai-nilai yang baru diperkenalkan.

Hasil penelitian ini menunjukan bahwa masih banyak PUS yang memiliki pengetahuan kurang yang masih tetap memanfaatkan pelayanan KB. PUS yang berpengetahuan kurang di Puskesmas Karang Intan 2 sebanyak 36 orang (36,0\%). Faktor pengetahuan merupakan salah satu unsur yang diperlukan dalam perubahan pola pikir dan perilaku. Adanya pengetahuan tentang jenis alat kontrasepsi, keuntunganya dan kerugiannya akan mempengaruhi seseorang untuk memilih jenis kontrasepsi yang sesuai. Dengan pengetahuan yang cukup tentang $\mathrm{KB}$ dapat di pastikan wanita pasang usia subur akan mempunyai sikap yang positif terhadap kontrasepsi.

\section{Kesimpulan}

1. Tidak ada hubungan antara pendidikan dengan pemanfaatan pelayanan alat kontrasepsi KB pada PUS di Puskesmas Karang Intan 2 Kabupaten Banjar Tahun 2019 ( $\mathrm{p}=$ 0,209).

2. Ada hubungan antara pengetahuan dengan pemanfaatan pelayanan alat kontrasepsi KB pada PUS di Puskesmas Karang Intan 2 Kabupaten Banjar Tahun 2019 ( $p=$ 0,016).

\section{Kepustakaan}

1. Adhyani AR. Faktor-Faktor yang Berhubungan dengan Pemilihan Kontrasepsi Non IUD pada Akseptor KB Wanita Usia 20-39 Tahun. Universitas Diponegoro; 2012.

2. Asridawati Akib. 2019. Faktor Yang Berhubungan Dengan Pemanfaatan Pelayanan Alat Kontrasepsi KB Pada Pasangan Usia Subur Di Puskesmas Tamalanrea Kota Makassar. Jurnal Farmasi Sandi Karsa Vol 5, Nomor 1.

3. Ayu Fitriani.2016. Hubungan Tingkat Pendidikan Penggunaan Kontrasepsi Dengan Jumlah Anak Yang Dilahirkan Wanita PUS.

4. BKKBN, RI. 2017. Panduan Pembangunan Keluarga Sejahtera Dalam Rangka Peningkatan Penanggulangan Kemiskinan, Jakarta: BKKBN

5. BKKBN Provinsi Kalimantan Selatan, 2018. 
6. Grestasari LE. Hubungan antara Tingkat Pendidikan, Pengetahuan, dan Usia Ibu Pus dengan Pemilihan Jenis Kontrasepsi di Desa Jetak Kecamatan Sidoharjo Kabupaten Sragen. Universitas Muhammadiyah Surakarta; 2014. 17.

7. Kementrian Kesehatan RI. 2015. Profil Kesehatan Indonesia Tahun 2014

8. Notoatmodjo S.2012. Promosi Kesehatan dan Perilaku Kesehatan. Jakarta: PT Rineka Cipta.

9. Mantra, Ida Bagus. 2012. Demografi Umum. Yogyakarta; Pustaka Pelajar.

10. Profil Kesehatan Puskesmas Karang Intan 2 Kota Makasar

11. Rifai, 2013. Faktor-faktor yang Berhubungan dengan Penggunaan Alat Kontrasepsi pada Pasangan Usia Subur Di Wilayah Puskesmas Buhu Kabupaten Gorontalo. DiAkses pada tanggal 1 Desember 2014 